\title{
PENERAPAN STRATEGI PEMBELAJARAN THINK PAIR SHARE UNTUK MENINGKATAN KEMAMPUAN BEKERJA SAMA ANAK DENGAN HAMBATAN EMOSI DAN PERILAKU DI SLB E BHINA PUTERA SURAKARTA
}

\author{
Fadilah Halfa Amatullah, Nandi Warnandi, Sunaryo \\ Departemen Pendidikan Khusus, Fakultas Ilmu Pendidikan, Universitan Pendidikan \\ Indonesia, Bandung, Indonesia \\ *fadilah_halfa@yahoo.com
}

\begin{abstract}
Children with emotional and behavioral disorders it difficult to teamwork because they think that their other friends are enemies and they must dominate everything. The impact is that children with emotional and behavioral disorders are less active in participating in learning activities. Researcher used the Think Pair Share learning strategy to increase the ability of teamwork for children with emotional and behavioral disorders at SLB E Bhina Putera Surakarta. The method used in this research is an experimental method with a one group pre-test post-test design. This research was conducted on six children with emotional and behavioral disorders in grade VI SDLB. The results showed an increase in the acquisition of post-test scores compared to the acquisition of pre-test scores. Based on the results of the research conducted, the researcher recommended the Think Pair Share learning strategy as an alternative to increase the ability of teamwork for children with emotional and behavior disorders.
\end{abstract}

Keywords: Think Pair Share, The Ability of Teamwork, Children with Emotional and Behavioral Disorders

\begin{abstract}
ABSTRAK
Anak dengan hambatan emosi dan perilaku kurang mampu untuk kerja sama karena menganggap teman lainnya adalah musuh dan dia harus menguasai semuanya. Dampaknya, anak dengan hambatan emosi dan perilaku kurang aktif mengikuti kegiatan pembelajaran. Peneliti mengunakan strategi pembelajaran Think Pair Share untuk meningkatkan kemampuan bekerja sama anak dengan hambatan emosi dan perilaku di SLB E Bhina Putera Surakarta. Metode yang digunakan dalam penelitian ini adalah metode eksperimen dengan design one group pre-test post-test. Penelitian ini dilakukan pada enam orang anak dengan hambatan emosi dan perilaku kelas VI SDLB. Hasil penelitian menunjukkan adanya peningkatan perolehan skor post-test dibandingkan dengan perolehan skor pre-test. Berdasarkan hasil penelitian yang dilakukan maka peneliti merekomendasikan strategi pembelajaran Think Pair Share sebagai salah satu alternatif untuk meningkatkan kemampuan bekerja sama anak dengan hambatan emosi dan perilaku.
\end{abstract}

Kata Kunci: Think Pair Share, Kemampuan Bekerja sama, Anak dengan hambatan Emosi dan Perilaku 


\section{JASSI_anakku Volume 20 Nomor 2, Desember 2020}

\section{Pendahuluan}

Dalam sebuah lingkungan, memiliki norma-norma yang harus dipatuhi oleh masyarakatnya. Seperti norma-norma perubahan perilaku pada anak-anak. Anak-anak yang tidak dapat mematuhi norma-norma yang berlaku cenderung dianggap bermasalah oleh masyarakat. Beberapa masalah tersebut ditunjukkan oleh anak secara jelas dengan intensitas dan frekeunsi yang berlebih dan durasi yang lebih lama dibandingkan anak normal lainnya. Hal tersebut, yang dialami oleh anak dengan hambatan emosi dan perilaku, yaitu menunjukkan perilaku menyimpang yang tidak sesuai dengan norma yang ada di masyarakat karena itu anak dengan hambatan emosi dan perilaku mengalami kesulitan dalam penyesuaian diri di lingkungan yang dapat merugikan diri sendiri dan orang lain.

Salah satu ciri yang menonjol pada anak dengan hambatan emosi dan perilaku adalah "kurang mampu kerja sama dan toleransi." (Atang Setiawan, 2009). Anak dengan hambatan emosi dan perilaku cenderung egois, tidak memikirkan orang lain, kurang bertanggung jawab dan tidak ada keinginan untuk bekerja sama dengan orang lain.

Manusia memiliki dinamika hidup di lingkungan masyarakat, yaitu sebagai makhluk sosial yang perkembangannya selalu berinteraksi dengan individu lain. Salah satu bentuk interaksi tersebut adalah bekerja sama antar individu. Bekerja sama adalah sebuah aktivitas yang dilakukan oleh beberapa orang dengan tujuan yang sama untuk mencapai sesuatu. Keterampilan kerja sama merupakan aspek kepribadian yang penting dan perlu dimiliki oleh setiap orang dalam kehidupan sosial di masyarakat (Apriano, 2011:160) dalam (Rosita \& Leonard, 2015)

Dalam dunia pendidikan, kemampuan bekerja sama merupakan hal penting yang harus dilaksanakan dalam pembelajaran. Kemampuan bekerja sama sangat penting dimiliki oleh siswa, karena siswa dapat saling berinteraksi dan saling membantu untuk mewujudkan tujuannya. Dengan adanya kemampuan bekerja sama dalam proses pembelajaran maka menuntut siswa untuk aktif mengikuti kegiatan pembelajaran. Dengan adanya kemampuan bekerja sama itu pula dapat membuat siswa lebih peduli dengan siswa lain atau individu lain dan belajar untuk mengurangi 


\section{JASSI_anakku Volume 20 Nomor 2, Desember 2020}

dan menghilangkan sifat egois dalam individu tersebut.

Dalam pembelajaran, guru berperan penting dalam keberhasilan suatu pembelajaran di kelas, sehingga guru dituntut menggunakan strategi dan inovasi pembelajaran yang bervariasi agar siswa bersemangat dan tidak jenuh di kelas. Banyak metode pembelajaran yang bisa digunakan oleh guru, namun tidak ada metode yang lebih baik. Untuk pemilihan metode pembelajaran perlu memerhatikan karakteristik materi, tujuan pembelajaran, waktu, dan jumlah siswa pada saat pembelajaran di kelas.

Dalam pembelajaran, salah satu metode pembelajaran yang lebih menitikberatkan pada kerja sama adalah Cooperative Learning (Pembelajaran Kooperatif). Menurut Slavin (1985) (dalam Isjoni, 2010, hlm. 15) mengemukakan bahwa pembelajaran kooperatif adalah model pembelajaran dimana siswa belajar dan bekerja dalam kelompok-kelompok kecil secara kolaboratif yang anggotanya 4-6 orang dengan struktur kelompok heterogen. Setiap anggota kelompok mempunyai tanggung jawab masing-masing atas hasil yang akan dicapai terhadap tugas yang diberikan oleh guru. Pembelajaran kooperatif menitikberatkan pada kerja sama dalam menyelesaikan tugas yang diberikan oleh guru pada siswa, sehingga siswa bertambah pengetahuannya atau prestasinya meningkat, komunikasi interaksi sosial dan kerja sama siswa juga akan tercipta dan meningkat. Selain dapat meningkatkan kerja sama, adanya kelompok-kelompok kecil dalam belajar dan anggota kelompok yang heterogen mempunyai dampak seperti relasi sosial, penerimaan siswa yang dianggap lemah, penghargaan terhadap waktu dan memberi pertolongan kepada orang lain.

Salah satu strategi pembelajaran kooperatif adalah strategi Think Pair Share. Merupakan strategi pembelajaran yang memberikan siswa waktu untuk berpikir dan merespon serta saling membantu antar teman. Melalui starategi pembelajaran Think Pair Share anak dengan hambatan emosi dan perilaku bisa bekerja sama dalam suatu tim untuk menyelesaikan suatu masalah, menyelesaikan tugas atau mengerjakan sesuatu secara bersama-sama.

Atas dasar permasalahan ini maka peneliti mengangkat judul "Penerapan Strategi Pembelajaran Think Pair Share untuk Meningkatkan Kemampuan Bekerja 


\section{JASSI_anakku Volume 20 Nomor 2, Desember 2020}

sama Anak dengan Hambatan Emosi dan Perilaku di SLB E Bhina Putera Surakarta" diharapkan penelitian ini bisa melatih sekaligus meningkatkan kemampuan bekerja sama anak dengan hambatan emosi dan perilaku dalam proses belajar mengajar.

\section{Metode Penelitian}

Penelitian ini menggunakan pendekatan kuantitatif dengan metode eksperimen. Menggunakan desain one-group pretest-posttest design, pada desain ini terdapat prestes terlebih dahulu sebelum diberi perlakuan. Dengan demikian, hasil perlakuan dapat diketahui lebih akurat karena dapat membandingkan dengan keadaan sebelum diberi perlakuan.

Di dalam penelitian ini, yang menjadi variabel bebas (x) adalah strategi pembelajaran Think Pair Share. Think Pair Share adalah salah satu strategi pembelajaran kooperatif yang memberikan siswa waktu untuk berpikir dan merespon serta saling membantu antar teman. Langkah pertama adalah think, guru mengajukan pertanyaan atau masalah yang berkaitan dengan pelajaranm dan siswa diminta untuk berpikir secara mandiri mengenai pertanyaan atau masalah tersebut. Langkah kedua adalah Pair, guru meminta siswa untuk berpasangan dan mendiskusikan mengenai apa yang telah dipikirkan, interaksi selama periode ini dapat menghasilkan jawaban bersama. Langkah ketiga adalah Share, guru meminta pasangan-pasangan tersebut berbagi hasil pemikiran mereka dengan pasangan lainnya.

Dalam penelitian ini variabel terikat (y) adalah kemampuan bekerja sama. Bekerja sama merupakan sebuah usaha yang dilakukan oleh beberapa orang atau kelompok untuk mencapai tujuan bersama. Adapun indikator kemampuan bekerja sama yang akan diamati adalah saling ketergantungan positif, tanggungjawab perorangan, komunikasi antar anggota, dan saling menghargai (Johnson) dalam (Edwi Gustikowendha, 2016). Untuk mengukur indikator kemampuan bekerja sama anak dengan hambatan emosi dan perilaku menggunakan instrument kemampuan bekerja sama yang dilaksanakan sebelum penelitian dan setelah pemberian perlakuan oleh

peneliti. Subjek pada penelitian ini yaitu 6 orang siswa kelas VI di SLB E Bhina Putera Surakarta. 


\section{JASSI_anakku Volume 20 Nomor 2, Desember 2020}

\section{Hasil dan Pembahasan}

Data hasil penelitian skor pre test dan post test kemampuan bekerja sama anak dengan hambatan emosi dan perilaku pada indikator saling ketergantungan positif, tanggungjawab perorangan, komunikasi antar anggota, dan saling menghargai. Dapat dilihat pada grafik dibawah ini:

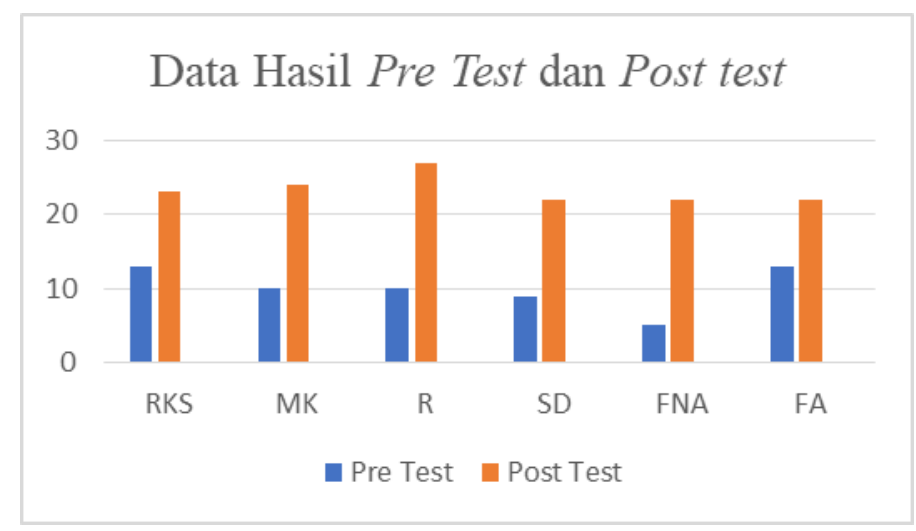

Gambar 1. Data hasl pretest-posttest

Grafik 1 menunjukkan bahwa ada peningkatan skor yang cukup signifikan. Subjek RKS mendapatkan skor pre test 13 dan post test mendapatkan 23, mengalami peningkatan skor 10 point. Subjek MK mendapatkan skor pre test 10 dan post test mendapatkan 24, mengalami peningkatan skor 14 point. Subjek R mendapatkan skor pre test 10 dan post test mendapatkan 27, mengalami peningkatan skor 17 point. Subjek SD mendapatkan skor pre test 9 dan post test mendapatkan 22, mengalami peningkatan skor 13 point. Subjek FNA mendapatkan skor pre test 5 dan post test mendapatkan 22, mengalami peningkatan skor 17 point. Subjek FA mendapatkan skor pre test 13 dan post test mendapatkan 22, mengalami peningkatan skor 9 point.

Berdasarkan penjelasan di atas dapat disimpulkan bahwa setiap subjek penelitian mengalami peningkatan skor. Skor terendah pada pre test adalah 5 dan skor tertinggi adalah 13. Setelah diberikan perlakuan dengan menggunakan strategi pembelajaran Think Pair Share, hasil skor terendah adalah 22 dan skor tertinggi adalah 27.

Hasil pengumpulan data yang diperoleh dari pre test dan post test, selanjutnya akan diuji hipotesis yang telah diajukan untuk diuji kebenarannya. Berdasarkan rumusan masalah dan kerangka berpikir, maka hipotesis dalam penelitian ini adalah terdapat peningkatan 


\section{JASSI_anakku Volume 20 Nomor 2, Desember 2020}

kemampuan bekerja sama anak dengan hambatan emosi dan perilaku melalui penerapan strategi pembelajaran Think Pair Share di SLB E Bhina Putera Surakarta.

Taraf nyata atau signifikansi yang digunakan adalah $(\alpha)=0,05$, berdasarkan uji Wilcoxon melalui SPSS versi 24 pada tabel 4.5 maka didapatkan hasil bahwa nilai Asymp. Sig $(2$-tailed $)=0,027$ kurang dari taraf signifikansi $(\alpha)=0,05(0,027<0,05)$ maka hipotesis nihil $\left(\mathrm{H}_{\mathrm{O}}\right)$ ditolak dan hipotesis kerja $\mathrm{H}_{\mathrm{a}}$ diterima. Jadi dapat disimpulkan bahwa terdapat peningkatan kemampuan bekerja sama anak dengan hambatan emosi dan perilaku melalui strategi pembelajaran Think Pair Share di SLB E Bhina Putera Surakarta.

\section{Kesimpulan}

Berdasarkan hasil penelitian yang telah dilakukan, dapat disimpulkan bahwa penerapan strategi pembelajaran Think Pair Share meningkatkan kemampuan bekerja sama anak dengan hambatan emosi dan perilaku di SLB E Bhina Putera Surakarta, ditunjukkan dengan adanya peningkatan perolehan skor setiap siswa yang cukup signifikan setelah diberikannya perlakuan.

\section{Referensi}

Isjoni, 2010, Pembelajaran Kooperatif Meningkatkan Kecerdasan Komunikasi antar Peserta Didik, Pustaka Pelajar. Yogyakarta.

Rosita, I. \& Leonard, L 2015, 'Meningkatkan Kerja Sama Siswa Melalui Pembelajaran Kooperatif Tipe Think Pair Share', Formatif: Jurnal Ilmiah Pendidikan MIPA, 3(1), 1-10. https://doi.org/10.30998/formatif.v3i1.108

Setiawan, A 2009, 'Mengembangkan Motivasi Belajar pada Anak Tunalaras', Jassi Anakku, 8(1), 54-60.

Gustikowendha, E.D 2016, 'Penerapan Model Pembelajaran Problem Based Learning untuk Meningkatkan Kerjasama dan Hasil Belajar pada Siswa Kelas IV SDN 4 Galanggag, Skripsi, Universitas Pasundan, Bandung. 